Review paper

\title{
A review of soil NO transformation: Associated processes and possible physiological significance on organisms
}

\author{
Sergiy Medinets a, b, c, Ute Skiba ${ }^{\text {d }}$, Heinz Rennenberg ${ }^{\text {c }}$, Klaus Butterbach-Bahl b, e, * \\ ${ }^{a}$ Regional Centre for Integrated Environmental Monitoring, Odessa National I. I. Mechnikov University (ONU), Mayakovskogo Lane 7, \\ 65082 Odessa, Ukraine \\ b Institute for Meteorology and Climate Research (IMK), Karlsruhe Institute of Technology (KIT), Kreuzeckbahnstraße 19, \\ D-82467 Garmisch-Partenkirchen, Germany \\ ${ }^{\mathrm{c}}$ Institute of Forest Sciences, University of Freiburg, Georges-Koehler-Allee 53/54, D-79110 Freiburg, Germany \\ d Centre for Ecology and Hydrology (CEH) Edinburgh, Bush Estate, Penicuik, Midlothian EH26 OQB, United Kingdom \\ e International Livestock Research Institute (ILRI), Old Naivasha Road, Nairobi, Kenya
}

\section{A R T I C L E I N F O}

\section{Article history:}

Received 10 June 2014

Received in revised form

23 August 2014

Accepted 28 September 2014

Available online 16 October 2014

\section{Keywords:}

Nitric oxide

Unspecific enzymo-oxidative mechanisms

NOS

SOD

Dissimilatory nitrate reduction to

ammonium

NO signaling

NO consumption

NO production

\begin{abstract}
A B S T R A C T
NO emissions from soils and ecosystems are of outstanding importance for atmospheric chemistry. Here we review the current knowledge on processes involved in the formation and consumption of NO in soils, the importance of NO for the physiological functioning of different organisms, and for inter- and intra-species signaling and competition, e.g. in the rooting zone between microbes and plants. We also show that prokaryotes and eukaryotes are able to produce NO by multiple pathways and that unspecific enzymo-oxidative mechanisms of NO production are likely to occur in soils. Nitric oxide production in soils is not only linked to NO production by nitrifying and denitrifying microorganisms, but also linked to extracellular enzymes from a wide range of microorganisms.

Further investigations are needed to clarify molecular mechanisms of NO production and consumption, its controlling factors, and the significance of NO as a regulator for microbial, animal and plant processes. Such process understanding is required to elucidate the importance of soils as sources (and sinks) for atmospheric NO.
\end{abstract}

(c) 2014 Elsevier Ltd. All rights reserved.

\section{Introduction}

Nitric oxide (nitrogen monoxide, NO) is a highly reactive constituent of the troposphere (Fowler et al., 2009) and is considered to be the main precursor of ground-level tropospheric ozone in rural areas (Chameides et al., 1994; Laville et al., 2011), impacting human health and plant productivity (Staffelbach et al., 1997; Ludwig et al., 2001). The main sources of NO in the troposphere are fossil fuel combustion, biomass burning, soil emissions and lightning (Delmas et al., 1997). Nevertheless agricultural soils can be the predominant NO source in rural regions, where the contribution of fossil fuel

\footnotetext{
* Corresponding author. Institute for Meteorology and Climate Research (IMK), Karlsruhe Institute of Technology (KIT), Kreuzeckbahnstraße 19, D-82467 Garmisch-Partenkirchen, Germany. Tel.: +49 8821183136.

E-mail addresses: s.medinets@gmail.com (S. Medinets), ums@ceh.ac.uk (U. Skiba), heinz.rennenberg@ctp.uni-freiburg.de (H. Rennenberg), klaus. butterbach-bahl@kit.edu (K. Butterbach-Bahl).
}

combustion is low (Bouwman et al., 2002; Butterbach-Bahl et al. 2009).

The global soil NO production is estimated at $\sim 8.9 \mathrm{Tg} \mathrm{N} \mathrm{a}^{-1}$, of which $\sim 15 \%$ is produced in Europe (IPCC, 2007). However, an earlier estimate by Davidson and Kingerlee's (1997) provided much higher values ranging from 13 to $21 \mathrm{Tg} \mathrm{N} \mathrm{a}{ }^{-1}$. Such large divergence between estimates results from insufficient knowledge of the full range of soil microbial processes involved in NO production and consumption and the interactions of these processes with environmental variables.

Biological $\mathrm{N}$ transformation processes in soils, namely nitrification and denitrification, are usually considered the dominant sources of soil NO production. However, also abiotic chemical N transformations can be an important source (Ludwig et al., 2001; Butterbach-Bahl et al., 2011, 2013). Linking NO production, consumption and emission to the source and sink processes of nitrification and denitrification in situ still remains challenging, as they can occur simultaneously and in the same soil aggregates (Arah, 